\title{
Influence of irradiance and spectral quality on the carbon metabolism of phytoplankton. I. Photosynthesis, chemical composition and growth
}

\author{
Richard B. Rivkin \\ Horn Point Environmental Laboratories, University of Maryland, Cambridge, Maryland 21613, USA
}

\begin{abstract}
Within the euphotic zone of oceans and lakes, planktonic algae are exposed to concurrent changes in irradiance and spectral quality. Most models of photoadaptations, however, consider only the effects of irradiance. Using a factorial experimental design, this study evaluated the influence of irradiance and spectral quality on the chemical composition, and rates of carbon uptake, polymer synthesis and cell division of 2 species of marine algae. Both the irradiance and spectral quality of light significantly $(p \leqslant 0.05)$ influenced the chemical composition and the patterns and rates of carbon uptake and polymer synthesis. Cell division rates were nat affected by light quality. Responses of the algae were complex and taxon-specific; however, there were several consistent patterns: for all spectral qualities, chlorophyll a, proteins and polysaccharides and the proportion of photosynthate incorporated into proteins were lower at high than low irradiances. At all irradiances, chlorophyll a was greater in white and blue than red light. Rates of protein synthesis, carbon uptake and respiration were greater in blue and red than white light of equal energy. Since there were distinct effects of irradiance and spectral quality on the metabolism and carbon uptake of marine phytoplankton, simulated in situ incubations which adjust irradiance but not spectral quality to in situ levels may not accurately estimate in situ rates of carbon uptake and protein metabolism. These experiments clearly show the importance of considering spectral quality in models of photoadaptation and primary production.
\end{abstract}

\section{INTRODUCTION}

The metabolism and growth of algae is regulated by both the intensity and spectral composition of light (Harris 1978, Morgan \& Smith 1981, Morris 1981, Prézelin 1981, Kowallik 1982, Richardson et al. 1983 and references cited therein). In nature, the photic regime experienced by a planktonic alga is not uniform. Different wavelengths of sunlight are attenuated by seawater at different rates. As a consequence, total energy decreases and spectral composition of downwelling light changes progressively with increasing depth. In oceanic regions, the longer wavelengths are selectively absorbed within the upper ca $10 \mathrm{~m}$ and only blue-green light remains. In contrast, in coastal regions, where concentrations of 'Gilvin' are high (Kirk 1983), the shorter wavelengths are rapidly absorbed (Jerlov 1968, Kirk 1983). Thus, different marine environments can have distinct spectral regimes. An alga which is vertically advected within the euphotic zone will experi- ence concurrent changes of intensity and spectral quality. Studies on the photoadaptations of phytoplankton should therefore consider the effects of both light intensity and light quality on metabolism and growth (Lewis et al. 1984, 1985a, b, 1988, Wood 1985, Glover et al. 1987. Cullen \& Lewis 1988). Most studies, however, consider only light intensity (Falkowski 1980, 1983, Prézelin 1981, Richardson et al. 1983, Falkowski et al. 1985). Here, the effects of irradiance and spectral regime on the metabolism and growth of marine phytoplankton are examined.

For a photoadaptation to benefit an alga, it should both compensate for the effects of a less-than-optimal photic regime and be expressed in altered rates of growth or cell division. Even when photoadaptations enhance the rates of carbon uptake at low irradiances or altered spectral compositions, the products of photosynthesis will often vary with changes in the light field. Since the intensity and quality of the downwelling light varies rapidly with depth, profound alterations in cellu- 


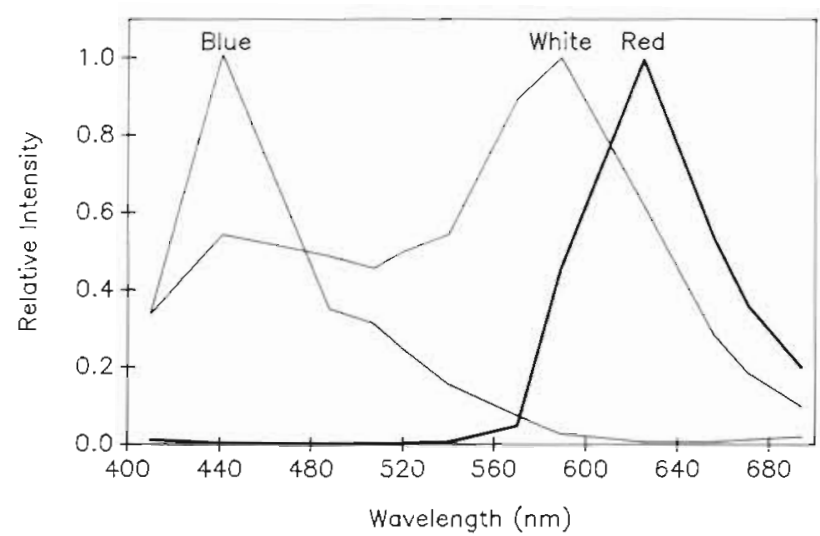

Fig. 1. Spectral composition of the white, red and blue light used to culture Dunaliella tertiolecta and Thalassiosira rotula Spectra were normalized to the wavelength of peak transmission for each color

lar metabolism can accur over relatively small vertical scales. Surprisingly, little is known about the quantitative changes in carbon uptake, polymer synthesis and growth which occur in response to changes in light quality. The influence of spectral quality on the physiology and growth of marine microalgae has been examined over the past 2 decades (Olive \& Morrison 1967. Wallen \& Geen 1971a, b, C, Faust et al. 1982, Glover et al. 1986, 1987 and others). However, most of these studies were not designed to rigorously test for separate effects of irradiance and spectral quality: thus, the interpretation of the results and their extrapolation to natural populations is tenuous (Morris 1981).

In this study, a factorial design was used to examine the influence of, and interactions between, irradiance and spectral quality on the metabolism and growth of 2 species of microalgae. The effects of intensity and quality of light on rates and patterns of polymer synthesis and growth were significant, distinct and taxonspecific. Results demonstrate the importance of considering the downwelling spectral irradiance in models of oceanic primary production.

\section{MATERIALS AND METHODS}

Culture conditions: Axenic cultures of Thalassiosira rotula, Meunier and Dunaliella tertiolecta, Butcher were grown in half-strength F-enriched $30 \%$ seawater (Guillard \& Ryther 1962) at $15 \pm 1{ }^{\circ} \mathrm{C}$ with a $12 \mathrm{~h} \mathrm{~L}$ : $12 \mathrm{~h} \mathrm{D}$ photoperiod of white, red or blue light. Cultures were maintained at each irradiance and spectral quality for at least $7 \mathrm{~d}$ prior to initiating experiments. Red and blue light were obtained by covering the fluorescent lights (General Electric Super High Output \# F48T12 CW SHO $1500 \mathrm{~mA}$ ) with Roscolux filters no. 19 and 69 , respectively. Photosynthetically active radia- tion (400 to $700 \mathrm{~nm} ; \mathrm{PAR}$ ) and spectral composition of the light (12 wavelengths with a $15 \mathrm{~nm}$ bandwidth between 400 and $700 \mathrm{~nm}$ ) were measured with a Biospherical Spectroradiometer (Model MER-1000) (Fig. 1). For each color, the photosynthetically usable radiation (PUR) incident on the culture flasks was adjusted to be equal by placing cultures at different distances from the light source and by covering the cultures with neutral density screens or filters (Roscolux No. 97). Photosynthetically usable radiation is the fraction of radiant energy which can be absorbed by an algal cell (Morel 1978, Gostan et al, 1986, Morel et al. 1987) and is defined as:

$$
\operatorname{PUR}=\int_{400 \mathrm{~mm}}^{700 \mathrm{~nm}} \operatorname{PAR}(\lambda) \operatorname{A}(\lambda)(\mathrm{d} \lambda)
$$

where $\operatorname{PAR}(\lambda)=$ spectral composition of the incident light; $A(\lambda)=a$ weighted probability function that a photon of a given wavelength will be absorbed by an algal cell: $A(\lambda)$ was estimated by normalizing the average in vivo absorption spectrum $[a(\lambda)]$ with respect to its absorption maximum $\left(a_{\max }\right)$, thus $A(\lambda)=a(\lambda) / a_{\max }$ (Gostan et al. 1986, Morel et al. 1987). For the 2 species studied, a max was 440 to $445 \mathrm{~nm}$. The in vivo absorption spectrum was determined, using a Cary recording spectrophotometer (Model 219), for an algal suspension collected on Whatman GF/C glass fiber filters (Truper \& Yentsch 1967). The filtrate of the cell suspension was refiltered onto a second glass fiber filter which was used as the reference.

Analytical techniques. Batch cultures were inoculated with exponentially growing cells to low initial densities and duplicated flasks were incubated at PUR of $12,40,120$ and 200 MEinst. $\mathrm{m}^{-2} \mathrm{~s}^{-1}$ of white, red and blue light. Cultures were subsampled daily; cells were counted with a hemocytometer or Palmer-Maloney counting chamber. For each photic regime, the dimensions of 30 to 50 cells were measured, using a calibrated ocular micrometer, and cell volumes calculated assuming the appropriate geometrical shape. Replicate $(n=3$ per assay) $5 \mathrm{ml}$ aliquots collected onto $25 \mathrm{~mm}$ precombusted $\left(500^{\circ} \mathrm{C}\right.$ for $6 \mathrm{~h}$ ) glass fiber filters (Whatman GF/C) were frozen at $-20^{\circ} \mathrm{C}$ until analyzed. Chlorophyll a (chl a) was measured fluorometrically (Rivkin 1985) and cell carbon (CAR) was determined by elemental analysis (Control Equipment Corp. CHN Analyzer, Model 240XA). Proteins (PRO), polysaccharides (POL), lipids (LIP) and low molecular weight (LMW) compounds were separated by serial solvent extraction (Li et al. 1980, Rivkin 1985). Specific polymer classes are extracted based on their relative solubilities in different solvents (Hitchcock 1983, Rivkin 1985), thus macromolecules were separated into functionally 
rather than metabolically defined classes of compounds. Lipids and LMW compounds were extracted into chloroform and methanol-water layers, respectively, using the chloroform-methanol-water solvent system (Bligh \& Dyer 1959). Polysaccharides were solubilized by boiling in $5 \%$ trichloroacetic acid (TCA) for $60 \mathrm{~min}$; proteins remained in the insoluble residue (however see Smucker \& Dawson 1986). Aliquots of the chloroform fraction were evaporated and lipids determined by dichromate oxidation method of Pande et al. (1963) using palmitic acid as a standard. Soluble polysaccharides were measured by the phenol-sulfuric acid method (Dubois et al. 1956) using glucose as a standard. Proteins in the hot TCA residue were dissolved in $1 \mathrm{ml}$ of $0.5 \mathrm{~N} \mathrm{NaOH}$ prior to assaying (Lowry et al. 1951).

Photosynthesis and polymer labelling patterns. During mid-exponential growth, cultures were inoculated with $\mathrm{NaH}^{14} \mathrm{CO}_{3}$ (final activity $=0.1 \mu \mathrm{Ci} \mathrm{ml}{ }^{-1}$ ) at the beginning of the light portion of the photoperiod. After ca $3,6,12$ and $24 \mathrm{~h}$, five $5 \mathrm{ml}$ aliquots were subsampled and total ${ }^{14} \mathrm{C}$-uptake (TOT) $(n=3)$ and the incorporation of ${ }^{14} \mathrm{C}$ into PRO, POL, LIP and LMW compounds $(n=2)$ were measured as previously described (Rivkin 1985). The same serial solvent extractions were used for the chemical and radioisotope analyses. The sum of radioactivity in the individual solvent fractions was 85 to $105 \%$ of the unfractionated (TOT) filters.

Growth and respiration. During exponential growth, the cell division rate $\left(\mu_{\mathrm{n}}\right.$; doublings $\left.\mathrm{d}^{-1}\right)$ was calculated from the least squares fit of the relationship between the logarithm of the cell number and time in days. The rates of carbon $\left(\mu_{c}\right)$, protein $\left(\mu_{\text {pro }}\right)$, polysaccharide $\left(\mu_{\text {poi }}\right)$ and lipid $\left(\mu_{\text {lip }}\right)$ specific growth (doublings $\mathrm{d}^{-1}$ ) were determined at each irradiance and spectral quality by

$$
\begin{aligned}
& \mu_{\mathrm{c}}=\left(\mathrm{dC}^{\prime} / \mathrm{dt}\right)[(\mathrm{CAR} \cdot)(\ln 2)]^{-1} \\
& \mu_{\mathrm{pro}}=(\mathrm{dPRO} / \mathrm{dt})[(\mathrm{PRO} \cdot)(\ln 2)]^{-1} \\
& \mu_{\mathrm{pol}}=\left(\mathrm{dPOL}^{\prime} / \mathrm{dt}\right)[(\mathrm{POL} \cdot)(\ln 2)]^{-1} \\
& \mu_{\text {lip }}=\left(\mathrm{dLIP}^{\prime} / \mathrm{dt}\right)\left[\left(\mathrm{LIP}^{*}\right)(\ln 2)\right]^{-1}
\end{aligned}
$$

where $\mathrm{C}^{\prime}=$ total ${ }^{14} \mathrm{C}$-carbon incorporation; $\mathrm{PRO}^{\prime}$, POL' and $\mathrm{LIP}^{\prime}={ }^{14} \mathrm{C}$-carbon incorporated into proteins, polysaccharides and lipids, respectively; $C A R \cdot$ $=$ cell carbon; and $\mathrm{PRO}^{\circ}, \mathrm{POL}^{*}$ and $\mathrm{LIP}^{*}=$ protein carbon, polysaccharide carbon and lipid carbon, respectively. The ratio, by weight, used to convert protein carbon to total protein was derived in 2 ways. First, the average fractional weight of carbon of 18 common amino acids and amides (alanine, arginine, aspartic acid, asparagine, glutamic acid, glutamine, glycine, histidine, isoleucine, leucine, lysine, methionine, phenylalanine, proline, serine, threonine, tyrosine and valine) was estimated to be $0.432 \pm$ 0.033 (mean \pm SEM). Second, using an average C:N ratio for protein of 3.2 (Reeck \& Fisher 1973, Jukes et al. 1975, DiTullio \& Laws 1983, 1986, Cuhel et al. 1984) and the standard agricultural conversion of cell nitrogen $\times 6.25=$ protein, protein carbon $=0.51$ total protein. The average conversion factor was protein carbon $=0.47$ total protein. POL $^{\circ}$ and LIP $^{\circ}$ were expressed as carbon equivalents and were determined from the weight percent of carbon in the glucose and palmitic acid standards, respectively.

Respiration was estimated from changes in particulate ${ }^{14} \mathrm{C}$ during the dark period (Laws \& Wong 1978 ,

\begin{tabular}{|c|c|c|c|c|c|}
\hline Irrad. & Chl a & Carbon & Protein & Polysaccharide & Lipid \\
\hline \multicolumn{6}{|l|}{ White } \\
\hline 12 & $0.72(0.036)$ & $42.5(1.93)$ & $28.3(2.87)$ & $93.3(1.58)$ & $46.5(6.32)$ \\
\hline 40 & $0.64(0.013)$ & $26.3(3.41)$ & $22.7(3.48)$ & $44.8(4.11)$ & $22.5(4.11)$ \\
\hline 120 & $0.18(0.006)$ & $22.8(2.24)$ & $13.0(1.08)$ & $29.3(2.87)$ & $15.3(0.86)$ \\
\hline 200 & $0.12(0.003)$ & $36.0(0.82)$ & $19.3(3.30)$ & $31.8(1.70)$ & $17.3(2.95)$ \\
\hline \multicolumn{6}{|l|}{ Red } \\
\hline 12 & $0.37(0.011)$ & $66.7(3.20)$ & $88.8(5.18)$ & $118(12.2)$ & $65.5(21.4)$ \\
\hline 40 & $0.30(0.017)$ & $44.3(1.72)$ & $17.0(1.42)$ & $55.3(1.75)$ & $54.0(6.23)$ \\
\hline 120 & $0.16(0.007)$ & $36.0(1.77)$ & $17.0(1.41)$ & $44.5(2.66)$ & $31.0(2.28)$ \\
\hline 200 & $0.13(0.009)$ & $26.8(2.13)$ & $17.5(1.19)$ & $51.8(1.60)$ & $28.3(2.28)$ \\
\hline \multicolumn{6}{|l|}{ Blue } \\
\hline 12 & $0.51(0.016)$ & $54.3(2.19)$ & $54.2(4.29)$ & $61.5(3.52)$ & $53.5(4.78)$ \\
\hline 40 & $0.40(0.028)$ & $47.0(1.78)$ & $36.6(2.95)$ & $58.8(3.30)$ & $26.5(9.04)$ \\
\hline 120 & $0.28(0.009)$ & $37.3(3.49)$ & $15.0(0.86)$ & $42.5(6.18)$ & $17.5(6.13)$ \\
\hline 200 & $0.12(0.007)$ & $37.3(1.49)$ & $20.0(3.70)$ & $42.3(5.62)$ & $19.0(2.10)$ \\
\hline
\end{tabular}
Cosper 1982). The dissolved organic ${ }^{14} \mathrm{C}$ carbon $\left(\mathrm{DO}^{14} \mathrm{C}\right)$

Table 1. Dunaliella tertiolecta. Chemical composition (pg cell $\left.{ }^{-1}\right)$ when grown at different irradiances $\left(\mu\right.$ Einst. $\left.\mathrm{m}^{-2} \mathrm{~s}^{-1}\right)$ of white, red and blue light. Values in parentheses are standard deviations $(n=4)$ 


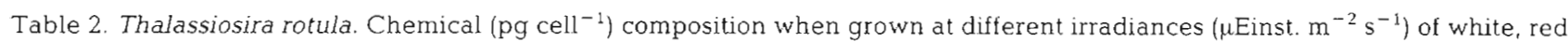
and blue light. Values in parentheses are standard deviations $(n=4)$

\begin{tabular}{|c|c|c|c|c|c|}
\hline Irrad. & Chl a & Carbon & Protein & Polysaccharide & Lipid \\
\hline \multicolumn{6}{|l|}{ White } \\
\hline 12 & $0.91(0.046)$ & $129(8.41)$ & $296(11.6)$ & $600(98.6)$ & $516(87.0)$ \\
\hline 40 & $0.64(0.033)$ & $147(8.62)$ & $191(20.8)$ & $336(72.0)$ & $518(83.5)$ \\
\hline 120 & $0.52(0.026)$ & $163(6.22)$ & $182(34.7)$ & $230(17.9)$ & $297(37.7)$ \\
\hline 200 & $0.52(0.033)$ & $171(6.56)$ & $141(10.5)$ & $174(13.1)$ & $216(29.3)$ \\
\hline \multicolumn{6}{|l|}{ Red } \\
\hline 12 & $0.63(0.031)$ & $153(9.67)$ & $471(78.8)$ & $561(51.8)$ & $583(82.1)$ \\
\hline 40 & $0.44(0.029)$ & $156(25.1)$ & $411(43.5)$ & $472(11.1)$ & $433(67.7)$ \\
\hline 120 & $0.37(0.023)$ & $198(10.9)$ & $250(23.6)$ & $375(39.9)$ & $387(37.8)$ \\
\hline 200 & $0.33(0.019)$ & $221(14.4)$ & $194(35.7)$ & $165(16.2)$ & $212(34.8)$ \\
\hline \multicolumn{6}{|l|}{ Blue } \\
\hline 12 & $0.81(0.066)$ & $195(12.2)$ & $335(60.2)$ & $664(69.1)$ & $388(47.5)$ \\
\hline 40 & $0.58(0.042)$ & $223(17.0)$ & $429(69.3)$ & $388(52.6)$ & $309(78.2)$ \\
\hline 120 & $0.47(0.029)$ & $182(24.5)$ & $253(20.1)$ & $234(32.4)$ & $266(34.6)$ \\
\hline 200 & $0.49(0.027)$ & 205 (12.9) & $188(28.7)$ & $277(31.4)$ & $177(28.9)$ \\
\hline
\end{tabular}

Table 3. Dunaliella tertiolecta and Thalassiosira rotula. Results of a 2-way Analysis of Variance by growth irradiance (Irr.) and spectral quality (Col.) for the changes in chemical composition

\begin{tabular}{|c|c|c|c|c|c|c|}
\hline & \multicolumn{3}{|c|}{ Dunaliella tertiolecta } & \multicolumn{3}{|c|}{ Thalassiosira rotula } \\
\hline & $F^{\mathrm{a}}$ & $p^{\mathrm{b}}$ & $r^{2 c}$ & $F^{a}$ & $p^{b}$ & $r^{2 c}$ \\
\hline \multicolumn{3}{|l|}{ Chlorophyll a } & 0.879 & & & 0.895 \\
\hline $\operatorname{Irr}$ & 185.22 & $<0.001$ & & 72.33 & $<0.001$ & \\
\hline Col. & 7.20 & 0.025 & & 3.40 & 0.044 & \\
\hline Irr. $\times$ Col & 37.51 & $<0.001$ & & 5.73 & $<0.001$ & \\
\hline \multicolumn{3}{|l|}{ Carbon } & 0.919 & & & 0.718 \\
\hline Irr. & 79.82 & $<0.001$ & & 4.79 & 0.007 & \\
\hline Col. & 33.81 & $<0.001$ & & 21.35 & $<0.001$ & \\
\hline Irr. $\times$ Col & 16.84 & $<0.001$ & & 5.73 & $<0.001$ & \\
\hline \multicolumn{3}{|l|}{ Protein } & 0.957 & & & 0.664 \\
\hline Irr. & 153.66 & $<0.001$ & & 13.59 & $<0.001$ & \\
\hline Col. & 30.77 & $<0.001$ & & 9.74 & $<0.001$ & \\
\hline Irr. $\times$ Col & 37.76 & $<0.001$ & & 1.83 & 0.121 & \\
\hline \multicolumn{3}{|l|}{ Polysaccharide } & 0.893 & & & 0.642 \\
\hline Irr & 71.50 & $<0.001$ & & 19.04 & $<0.001$ & \\
\hline Col. & 15.84 & $<0.001$ & & 0.89 & 0.420 & \\
\hline Irr. $\times$ Col. & 8.88 & $<0.001$ & & 0.94 & 0.480 & \\
\hline \multicolumn{3}{|l|}{ Lipid } & 0.784 & & & 0.460 \\
\hline Irr. & 7.33 & 0.001 & & 6.85 & $<0.001$ & \\
\hline Col. & 7.39 & 0.002 & & 1.49 & 0.238 & \\
\hline Irr. $\times$ Col & 3.45 & 0.009 & & 0.32 & 0.923 & \\
\hline $\begin{array}{l}\text { ' Critical F-ratio } \\
\text { b Probability: } p \\
{ }^{\circ} \text { Correlation co }\end{array}$ & \multicolumn{4}{|c|}{${ }^{b}$ Probability: $p>0.05$, not significant; $p \leq 0.05$, significant; $p \leq 0.01$, highly significant; $p \leq 0.001$, very highly significant } & 1, very $h$ & nificant \\
\hline
\end{tabular}

released during the dark period was measured during experiments by acidifying and bubbling subsamples of the filtrate with filtered air (Sharp 1977). DO ${ }^{14} \mathrm{C}$ was negligible for all conditions (Rivkin unpubl.).

Radiation counting. Radioactivity was counted using a Packard Tri-Carb (Model 460 C) liquid scintillation spectrometer with Biofluor as a scintillant. All counts were corrected for quench by the external standards method and for background radiation. Separate quench corrections were used for each solvent.

Statistical treatment of data. The significance of the different treatments (e.g. irradiance, color and incubation time) was evaluated by an ANOVA F-test. An a priori test, such as an ANOVA, tests for significance 
Table 4. Dunaliella tertiolecta and Thalassiosira rotula. Influence of incubation irradiance and color on chemical composition. The Bonferroni (Dunn) multiple comparison test was used to test for significant $(p \leq 0.05)$ differences among means ( $n=$ number of observations per treatment)

\begin{tabular}{|lll|}
\hline & Dunaliella tertiolecta & Thalassiosira rotula \\
\hline Irradiance & & \\
Protein & $(n=12)$ & $(n=12)$ \\
Polysaccharide & $12>40>120=200$ & $12=40>120=200$ \\
Lipid & $12>40>120=200$ & $12>40=120=200$ \\
Carbon & $12=40>120=200$ & $12=40=120=200$ \\
Chlorophyll a & $12>40>120<200$ & $12<40=120=200$ \\
Color & $12>40>120>200$ & $12>40>120=200$ \\
Protein & $(n=12)$ & $(n=12)$ \\
Polysaccharide & $\mathrm{W}<\mathrm{R}=\mathrm{B}$ & $\mathrm{W}<\mathrm{R}=\mathrm{B}$ \\
Lipid & $\mathrm{W}<\mathrm{R}>\mathrm{B}$ & $\mathrm{W}=\mathrm{R}=\mathrm{B}$ \\
Carbon & $\mathrm{W}<\mathrm{R}>\mathrm{B}$ & $\mathrm{W}=\mathrm{R}=\mathrm{B}$ \\
Chlorophyll a & $\mathrm{W}<\mathrm{R}=\mathrm{B}$ & $\mathrm{W}<\mathrm{R}=\mathrm{B}$ \\
& $\mathrm{W}>\mathrm{R}<\mathrm{B}$ & $\mathrm{W}>\mathrm{R}<\mathrm{B}$ \\
12, 40,120 and $200 \mu$ Einst. $\mathrm{m}^{-2} \mathrm{~s}^{-1}$ & & \\
b: white; R: red; B: blue & & \\
\hline
\end{tabular}
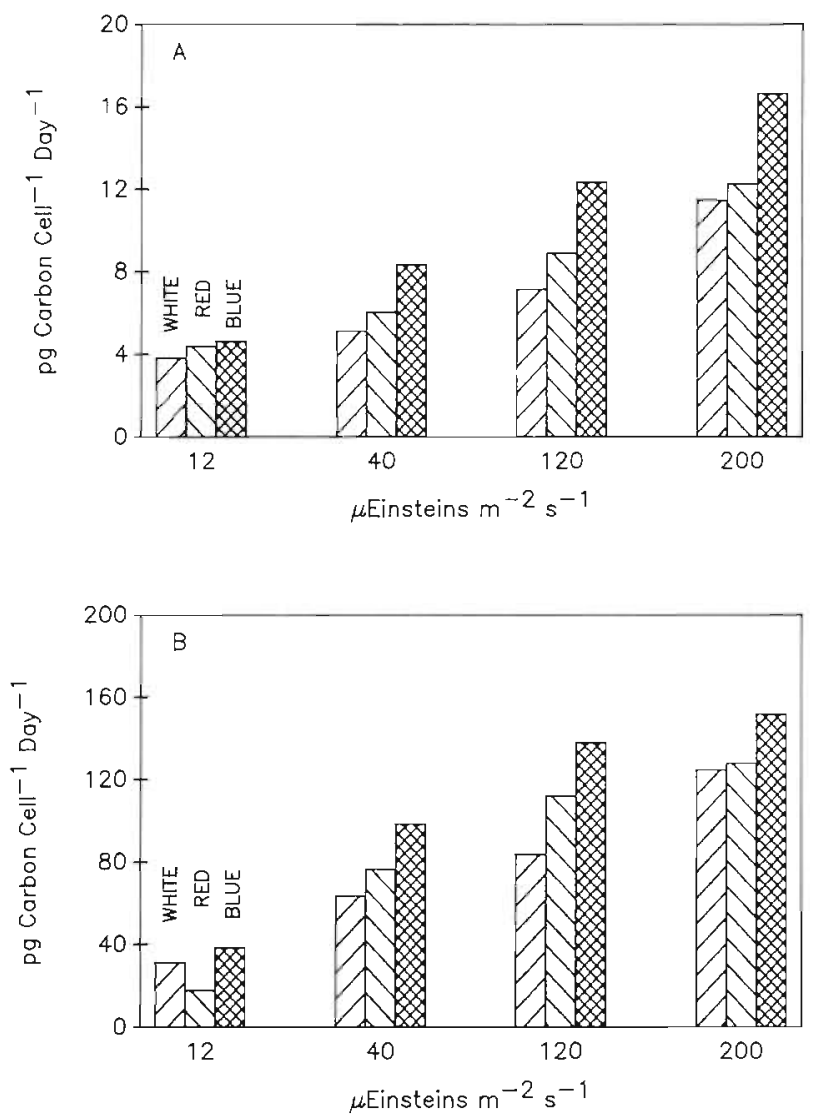

Fig. 2. Rates of daily carbon uptake by (A) Dunaliella tertiolecta and (B) Thalassiosira rotula grown at 12,40,120 and $200 \mu$ Einst. $\mathrm{m}^{-2} \mathrm{~s}^{-1}$ of white, red and blue light

assuming a complete null hypothesis, but not for significance under a partial null hypothesis (i.e. when some of the means are equal and others differ). Thus, ANOVA does not distinguish which of the means were signifi- cantly different. An a posteriori multiple comparison test, such as the Bonferroni multiple comparison test used here, determines whether differences among means at the different levels (e.g. the 4 different irradiances) within a treatment are significant, and the magnitude of the differences. This test has been widely used for the simultaneous statistical testing of more than one hypothesis (Einot \& Gabriel 1975, Miller 1981).

\section{RESULTS}

\section{Chemical composition}

Both irradiance and spectral quality influenced the chemical composition of Dunaliella tertiolecta (Tables 1 and 3) and Thalassiosira rotula (Tables 2 and 3). Twoway analysis of variance demonstrated that the differences in chemical composition among most of the different irradiances and spectral qualities were significant (Table 3). Furthermore, there were significant synergistic interactions between irradiance and spectral quality for all the chemical components measured in $D$. tertiolecta, but only for chl a and CAR in T. rotula (Table 3). Cell volumes were similar for all photic regimes. $D$. tertiolecta was $920 \pm 155 \mu \mathrm{m}^{3}$ and $T$. rotula was $9700 \pm 1050 \mu^{3}$ (mean $\pm \mathrm{SD}$ ).

For both algae, chl $a$, PRO, POL and LIP were usually greater at low than high irradiances (Tables 1, 2 and 4). In Dunaliella tertiolecta CAR was usually greater at low than at high irradiances (Tables 1 and 4), whereas in Thalassiosira rotula CAR was either not influenced by light or was greater at high than at low irradiances (Tables 2 and 4). For both species, chl a was greater in white than blue or red light and PRO and CAR was 
greater in blue and red than white light of equal PUR (Tables 1,2 and 4). Polysaccharides and LIP were usually higher in red than blue or white light in $D$. tertiolecta (Tables 1 and 4), whereas they were not influenced by spectral quality in $T$. rotula (Tables 2 and 4 ).

\section{Photosynthesis, respiration and growth}

Carbon uptake rates were influenced by both irradiance and spectral quality (Fig. 2, Table 5). For both species, photosynthetic performance (i.e. the rate of photosynthesis at the growth irradiance) was significantly greater $(p \leqslant 0.05)$ in blue than red or white light
(Table 5). An insufficient number of irradiances were tested to determine if $200 \mu$ Einst. $\mathrm{m}^{-2} \mathrm{~s}^{-1}$ saturated ${ }^{14} \mathrm{C}$ uptake or to calculate photosynthetic parameters.

Daily respiration was estimated by doubling the rate of loss of particulate ${ }^{14} \mathrm{C}$ measured during the $12 \mathrm{~h}$ dark period. For both species, respiration expressed as a rate (pg carbon cell ${ }^{-1} \mathrm{~d}^{-1}$ ) and as a percent of daily carbon production (i.e. [carbon respired in $24 \mathrm{~h} /$ carbon incorporated during the $12 \mathrm{~h}$ light period] $\times 100)(\%-P)$ was significantly greater (ANOVA, $p \leqslant 0.05$ ) at high than at low irradiances (Table 6) and in blue than red or white light (Table 6).

Rates of cell division were independent of the spectral quality (Fig. 3). An insufficient number of irradian-

Table 5. Dunaliella tertiolecta and Thalassiosira rotula. Influence of incubation irradiance, color and time on the incorporation of carbon (Tot.; pg carbon cell ${ }^{-1}$ ) and the labelling patterns of proteins (Pro.), polysaccharides (Pol.), lipids (Lip.) and low molecular weight compounds (LMW). Labelling patterns expressed as a percent of total carbon incorporated. The Bonferroni (Dunn) multiple comparison test was used to test for significant $(p \leq 0.05)$ differences among means $(n=$ number of observations per treatment). Values in parentheses are means for each condition

\begin{tabular}{|c|c|c|}
\hline & Dunaliella tertiolecta & Thalassiosira rotula \\
\hline Irradiance $^{\mathrm{a}}$ & $(n=24)$ & $(n=24)$ \\
\hline Pro. & $\begin{array}{l}12=40>120=200 \\
(36)(36) \\
(30)\end{array}$ & $\begin{array}{l}12=40>120=200 \\
(56) \quad(57) \quad(54)\end{array}$ \\
\hline Pol. & $\begin{array}{l}12=40<120=200 \\
(22)(25) \quad(37)\end{array}$ & $\begin{array}{l}12>40=120=200 \\
(16)(11) \quad(11)\end{array}$ \\
\hline Lip. & $\begin{array}{l}12=40>120<200 \\
(28)(28)(21)\end{array}$ & $\begin{array}{l}12=40<120=200 \\
(17)(16) \quad(21) \quad(20)\end{array}$ \\
\hline LMW & $\begin{array}{l}12>40=120>200 \\
(14)(10) \quad(12)\end{array}$ & $\begin{array}{l}12=40=120<200 \\
(17)(16) \quad(14) \quad(18)\end{array}$ \\
\hline Tot. & $\begin{array}{l}12<40<120<200 \\
(3) \quad \text { (5) }\end{array}$ & $\begin{array}{l}12<40<120<200 \\
(20)(62) \quad(83) \quad(103)\end{array}$ \\
\hline Color ${ }^{b}$ & $(n=32)$ & $(n=32)$ \\
\hline Pro. & $\begin{array}{l}W<R=B \\
\text { (29) (33) (34) }\end{array}$ & $\begin{array}{l}W=R<B \\
(53)(52)(58)\end{array}$ \\
\hline Pol. & $\begin{array}{l}W>R>B \\
\text { (34) (31) (26) }\end{array}$ & $\begin{array}{l}W<R>B \\
(10)(14)(12)\end{array}$ \\
\hline Lip. & $\begin{array}{l}W=R<B \\
(24)(24)(27)\end{array}$ & $\begin{array}{l}W=R>B \\
(19)(18)(16)\end{array}$ \\
\hline LMW & $\begin{array}{l}W=R=B \\
(13)(12)(13)\end{array}$ & $\begin{array}{l}W<R=B \\
(13)(16)(18)\end{array}$ \\
\hline Tot. & $\begin{array}{l}W<R<B \\
\text { (5) (7) (9) }\end{array}$ & $\begin{array}{l}W<R<B \\
(58)(63)(81)\end{array}$ \\
\hline$T^{T i m e} e^{c}$ & $(n=24)$ & $(n=24)$ \\
\hline Pro. & $\begin{array}{l}3=6=12<24 \\
(18)(29)(31)(45)\end{array}$ & $\begin{array}{l}3=6=12<24 \\
(53)(51)(49)(63)\end{array}$ \\
\hline Pol. & $\begin{array}{l}3<6=12>24 \\
(29)(35)(37)(21)\end{array}$ & $\begin{array}{l}3=6=12=24 \\
(14)(12)(1.1)(12)\end{array}$ \\
\hline Lip. & $\begin{array}{l}3=6>12<24 \\
(26)(25)(22)(18)\end{array}$ & $\begin{array}{l}3=6=12>24 \\
(16)(18)(20)(15)\end{array}$ \\
\hline LMW & $\begin{array}{l}3>6=12>24 \\
(17)(11)(10)(6)\end{array}$ & $\begin{array}{l}3=6<12>24 \\
(17)(16)(20)(10)\end{array}$ \\
\hline Tot. & $\begin{array}{l}3<6<12>24 \\
(4) \quad(6) \quad(9) \quad(8)\end{array}$ & $\begin{array}{l}3<6<12>24 \\
(29)(58)(99)(83)\end{array}$ \\
\hline \multicolumn{3}{|c|}{$\begin{array}{l}12,40,120 \text { and } 200 \mu \text { Einst. } \mathrm{m}^{-2} \mathrm{~s}^{-1} \\
\text { 'W: white; R: red; B: blue } \\
\text { "Incubation time with }{ }^{14} \mathrm{C}(3,6,12 \text { and } 24 \mathrm{~h}) \text {. The } 12 \text { to } 24 \mathrm{~h} \text { interval was during the dark portion of the photoperiod }\end{array}$} \\
\hline
\end{tabular}


Table 6. Dunaliella tertiolecta and Thalassiosira rotula. Rates of respiration (Resp; pg carbon cell ${ }^{-1} \mathrm{~d}^{-1}$ ), and respiratory loss as a percent of daily production ([carbon respired in $24 \mathrm{~h} /$ carbon taken up during the $12 \mathrm{~h}$ light period] $\times 100 ; \%$-P) when grown in different irradiances ( $\mu$ Einst. $\mathrm{m}^{-2} \mathrm{~s}^{-1}$ ) of white, red and blue light

\begin{tabular}{|c|c|c|c|c|c|c|c|}
\hline \multirow[t]{2}{*}{ Irrad. } & & \multicolumn{3}{|c|}{ Dunaliella tertiolecta } & \multicolumn{3}{|c|}{ Thalassiosira rotula } \\
\hline & & White & Red & Blue & White & Red & Blue \\
\hline \multirow[t]{2}{*}{12} & Resp. & 0.29 & 0.79 & 1.28 & 1.12 & 5.96 & 9.33 \\
\hline & $\%-\mathrm{P}$ & 5.8 & 11.7 & 22.6 & 5.8 & 17.2 & 24.3 \\
\hline \multirow[t]{2}{*}{40} & Resp. & 0.46 & 2.12 & 2.16 & 9.39 & 17.8 & 33.3 \\
\hline & $\%-\mathrm{P}$ & 8.5 & 22.1 & 29.8 & 12.5 & 20.7 & 27.7 \\
\hline \multirow[t]{2}{*}{120} & Resp. & 0.91 & 3.08 & 3.12 & 16.5 & 29.9 & 40.5 \\
\hline & $\%-\mathrm{P}$ & 12.0 & 29.6 & 31.2 & 17.3 & 23.9 & 28.9 \\
\hline \multirow[t]{2}{*}{200} & Resp. & 1.44 & 4.10 & 6.97 & 27.9 & 34.8 & 49.8 \\
\hline & $\%-P$ & 11.8 & 30.8 & 33.1 & 19.0 & 25.5 & 29.6 \\
\hline
\end{tabular}

ces were tested to permit a detailed growth-irradiance curve to be constructed; however, the maximum cell division rates of ca 0.5 doublings $\mathrm{d}^{-1}$ for Dunaliella tertiolecta (Fig. 3A) and ca 1.1 doublings $\mathrm{d}^{-1}$ for Thalassiosira rotula (Fig. 3B) appeared to saturate by ca $200 \mu$ Einst. $\mathrm{m}^{-2} \mathrm{~s}^{-1}$.

\section{Carbon uptake and polymer synthesis}

The patterns of ${ }^{14} \mathrm{C}$-uptake (TOT) and its incorporation into PRO, POL; LIP and LMW compounds were statistically evaluated by a 3-way ANOVA F-test (Table 7) and the Bonferroni multiple comparison test (Table 5). With the exception of color on LMW compounds, there were significant effects of color, irradiance and time on carbon uptake and polymer synthesis by Thalassiosira rotula and Dunaliella tertiolecta. Moreover, significant interactions among color, irradiance and time occurred in 34 of 40 cases (Table 7).

Since the differences among treatments were significant, the effects of the different levels within a treatment were statistically evaluated. The polymer-labelling patterns of Dunaliella tertiolecta and Thalassiosira rotula differed (Table 5). For all colors, irradiances and incubation times, $T$. rotula incorporated a significantly $(p \leqslant 0.05)$ larger proportion of its photosynthate into PRO (50 to $60 \%$ ) and a smaller proportion into POL (15 to $20 \%$ ) and LIP (15 to $20 \%$ ) than D. tertiolecta (25 to $35 \%, 25$ to $35 \%$ and 25 to $30 \%$, respectively).

Although the influences of color, irradiance and incubation time on the patterns of polymer synthesis were complex and often species-specific, several trends emerged (Table 5). (1) At all irradiances, both species incorporated a significantly larger proportion of their photosynthate into PRO in blue than red or white light. The proportion of ${ }^{14} \mathrm{C}$ which Dunaliella tertiolecta incorporated into LIP was smaller and that incorpo-
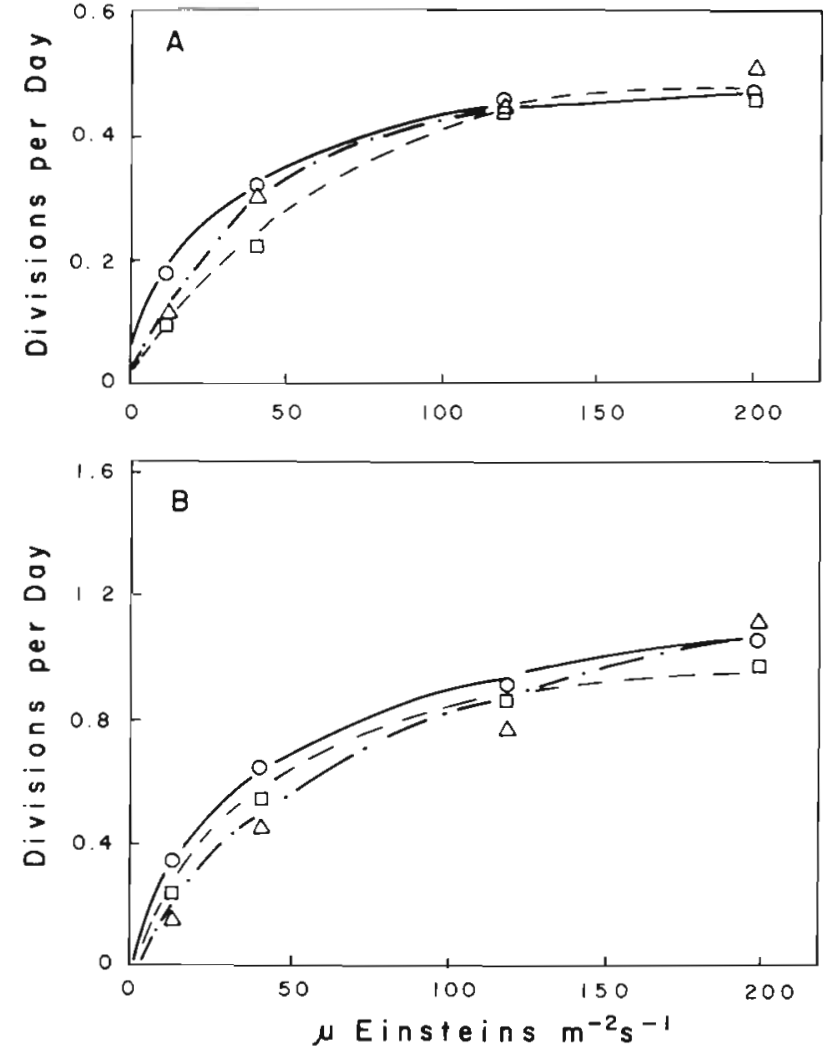

Fig. 3. Rates of cell division by (A) Dunaliella tertiolecta and (B) Thalassiosira rotula grown at $12,40,120$ and $200 \mu$ Einst. $\mathrm{m}^{-2} \mathrm{~s}^{-1}$ of white $(0)$, red $(\Delta)$, and blue (ㅁ) light

rated into POL was larger in white than blue (or red) light. In contrast, the proportion of ${ }^{14} \mathrm{C}$ which Thalassiosira rotula incorporated into LIP was greater and that incorporated into POL and LMW compounds was generally lower in white than blue (or red) light of equal PUR (Table 5). (2) For all spectral qualities, both species incorporated a larger proportion of their photosynthate into PRO at low than at high irradiances. The proportion of ${ }^{14} \mathrm{C}$ which $D$. tertiolecta incorporated into LIP 
Table 7. Dunaliella tertiolecta and Thalassiosira rotula. Results of a 3-way Analysis of Variance by growth irradiance (Irr.), spectral quality (Col.) and time (Tim.) for the incorporation of carbon and the photosynthate labelling patterns (expressed as percent of ${ }^{14} \mathrm{C}$ incorporated) during time-course experiments

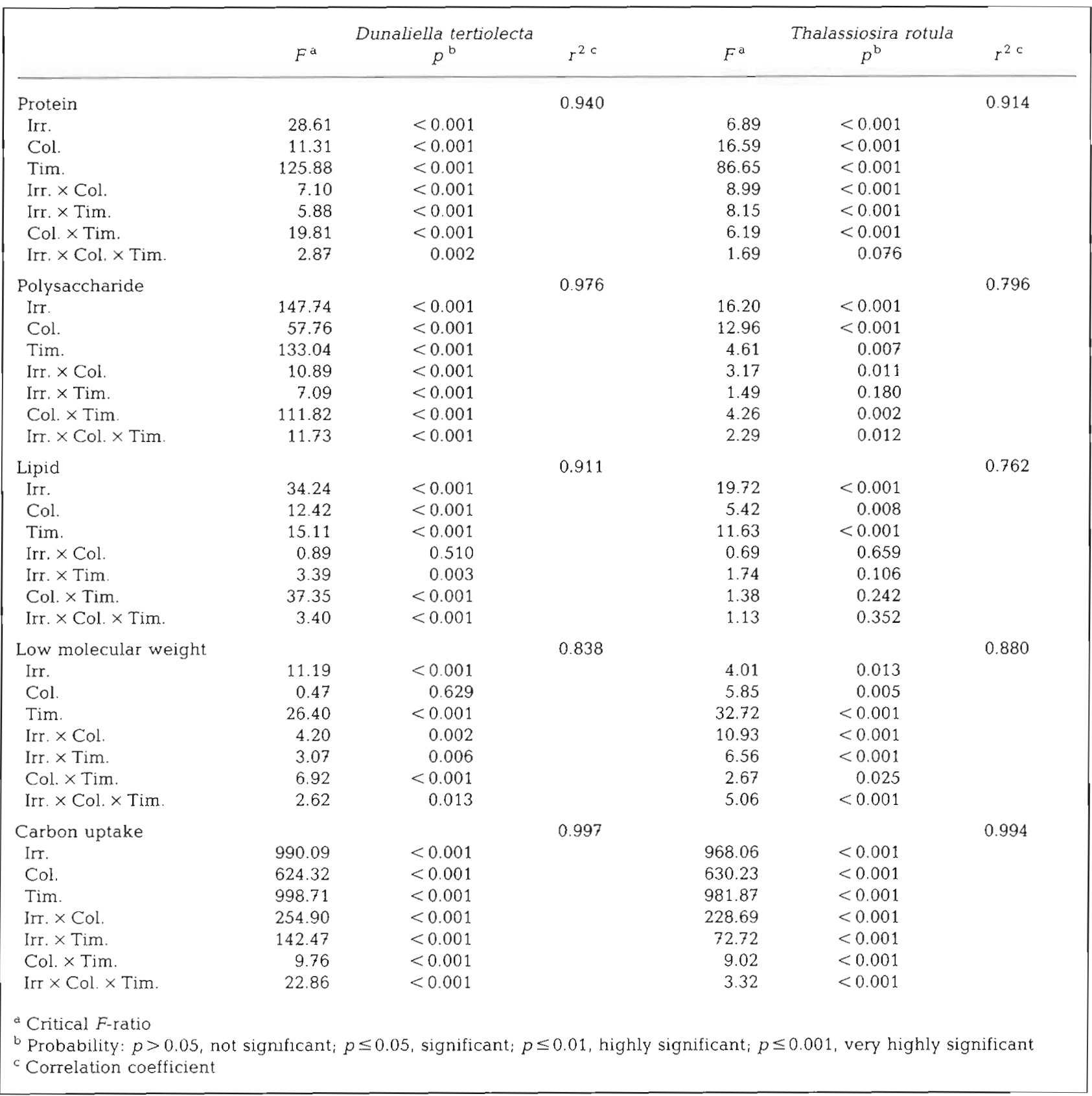

and LMW compounds was larger and that incorporated into POL was smaller at low than at high irradiances. In contrast, $T$. rotula incorporated a larger proportion of its photosynthate into POL and a smaller proportion into LIP and LMW compounds at low than high irradiances (Table 5).

There was a significant reallocation of carbon among polymer pools during the $12 \mathrm{~h}$ dark interval. To facilitate a comparison among photic regimes and polymer pools the data were presented as a percent change during the $12 \mathrm{~h}$ dark period (i.e. $100 \times$ Ipg polymer carbon cell ${ }^{-1}$ at $12 \mathrm{~h}-\mathrm{pg}$ polymer carbon cell ${ }^{-1}$ at $24 \mathrm{hl} / \mathrm{pg}$ polymer carbon cell ${ }^{-1}$ at $12 \mathrm{~h}$ ). Both the percent ${ }^{1.4} \mathrm{C}$ activity in, and size (e.g. the product of the percent incorporation and the total ${ }^{14} \mathrm{C}$ uptake) of, the PRO pool increased during the dark period (Table 5, Figs. 4 and 5): the proportional increase in PRO was greater for Dunaliella tertiolecta (20 to $80 \%$ ) than for 
Thalassiosira rotula (10 to $25 \%$ ). For both algae, more CAR was reallocated into $P R O$ in blue than white or red light of equal PUR (Figs, 4 and 5). In D. tertiolecta, the reallocation of ${ }^{14} \mathrm{C}$ into $\mathrm{PRO}$ during the dark interval was generally greater at high than low growth irradiances (Fig. 4). The increase of ${ }^{14} \mathrm{C}$ in PRO was accom-
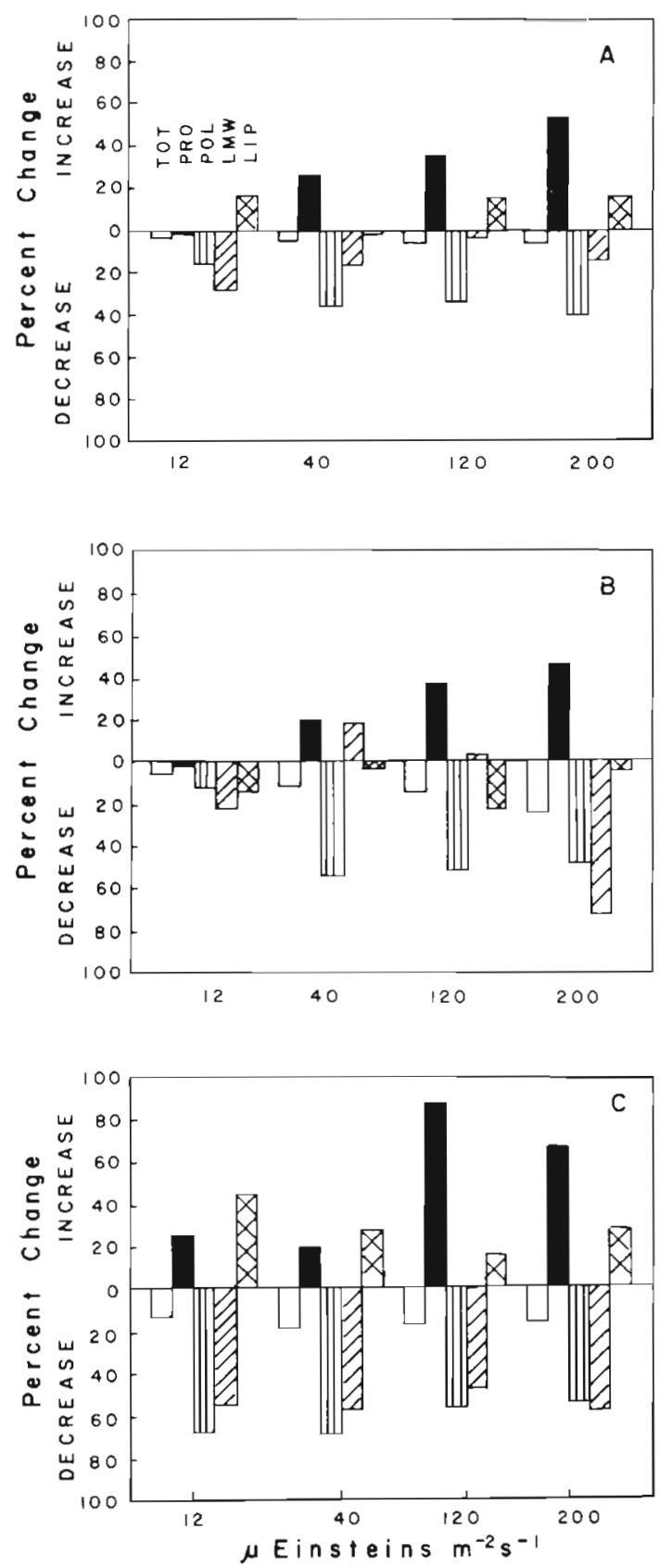

Fig. 4. Dunaliella tertiolecta. Change in total particulate ${ }^{14} \mathrm{C}$ (TOT) and ${ }^{14} \mathrm{C}$-activity in the protein (PRO), polysaccharide (POL), low molecular weight (LMW) and lipid (LIP) pools during the $12 \mathrm{~h}$ dark interval for cells grown at $12,40,120$ and $200 \mu$ Einst. $\mathrm{m}^{-2} \mathrm{~s}^{-1}$ of (A) white, (B) red and (C) blue light. See text for details of calculation panied by concomitant decreases in the POL and LMW fractions (Fig. 4). In addition, there was a small but consistent increase in LIP during the dark period when grown in the blue and white (Figs. 4A, C) but not red light regimes (Fig. 4B). In $T$. rotula, the irradiance did not appear to influence the reallocation of ${ }^{14} \mathrm{C}$ into PRO
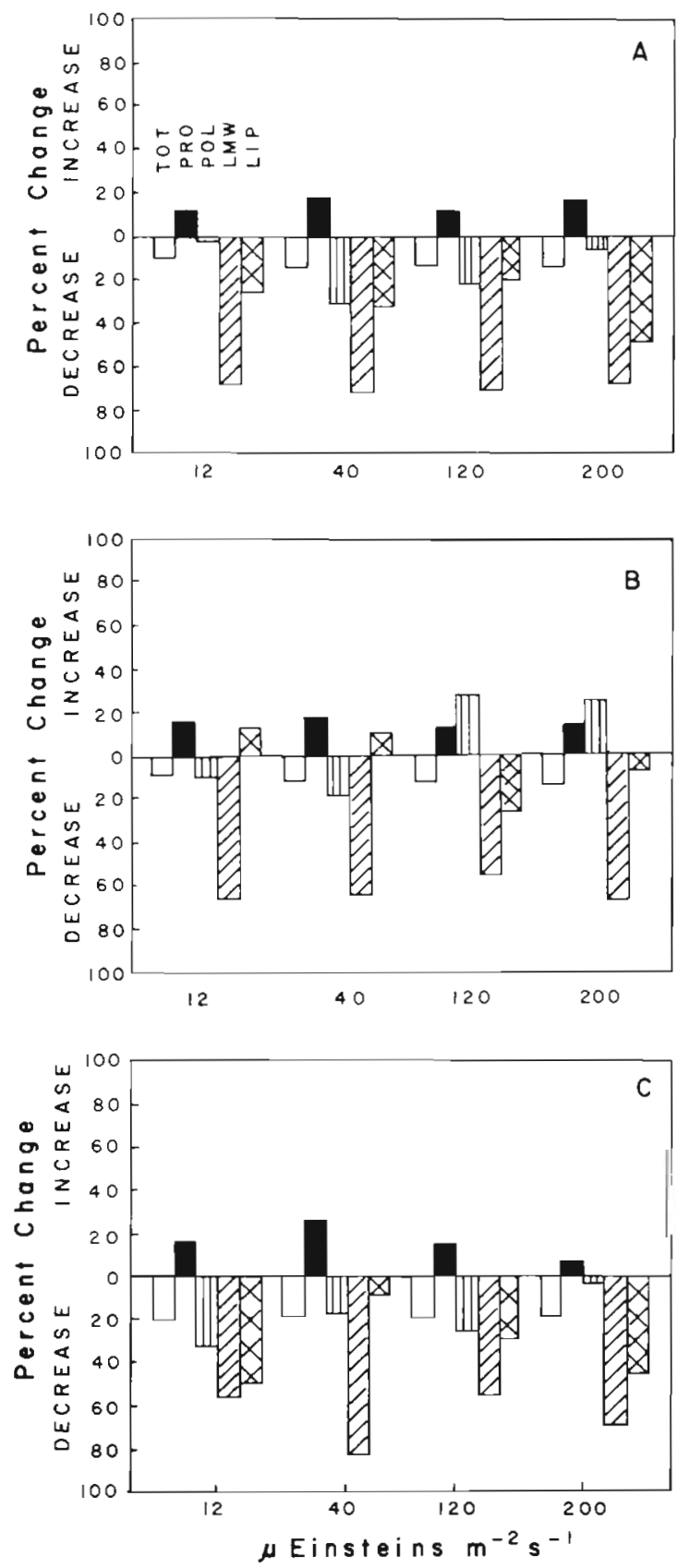

Fig. 5. Thalassiosira rotula. Change in total particulate ${ }^{14} \mathrm{C}$ (TOT) and ${ }^{14} \mathrm{C}$-activity in the protein (PRO), polysaccharide (POL), low molecular weight (LMW) and lipid (LIP) pools during the $12 \mathrm{~h}$ dark interval for cells grown at $12,40,120$ and $200 \mu$ Einst. $\mathrm{m}^{-2} \mathrm{~s}^{-1}$ of (A) white, (B) red and (C) blue light. See text for details of calculation 

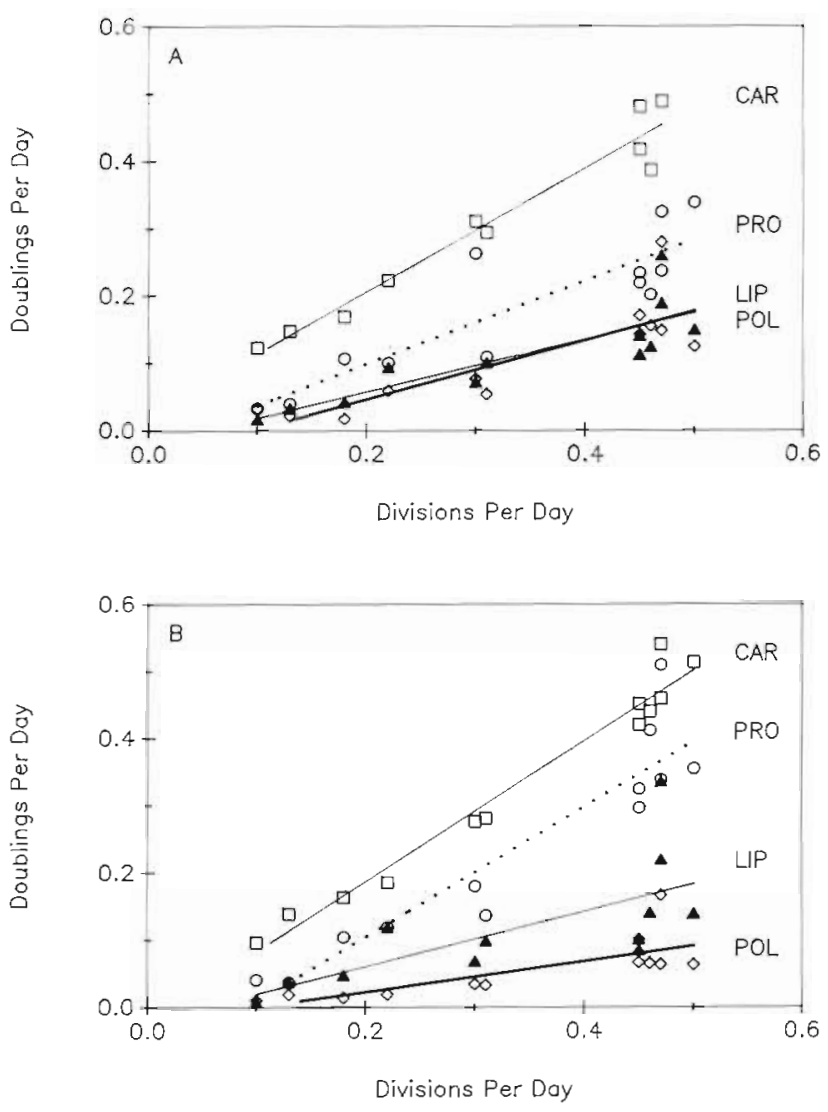

Fig. 6. Dunaliella tertiolecta. Relationship between rates of cell division (divisions $\mathrm{d}^{-1}$ ) and carbon (CAR) (C), protein (PRO) (0), polysaccharide (POL) ( $\diamond)$, and lipid (LIP) ( 1 ) specific growth (doublings $\mathrm{d}^{-1}$ ) determined during (A) $12 \mathrm{~h}$ incubations in the light and (B) $24 \mathrm{~h}$ incubations (12 h light: $12 \mathrm{~h}$ dark)

during the dark interval. The increase in PRO was usually accompanied by decreases in the LIP and LMW fractions (Fig. 5).

The irradiance and spectral quality dependent rates of carbon, protein, polysaccharide and lipid specific growth were calculated according to Eqs. (2) to (5), respectively. Since carbon was reallocated among polymer pools during the dark period, the rates were determined for $12 \mathrm{~h}$ (light period only) and $24 \mathrm{~h}$ (light plus dark period) incubations. In all cases there were significant linear relations between rates of carbon or polymer specific growth and that of cell division (Figs. 6 and 7 ). The regression statistics are summarized in Table 8 . For both algae, the regression coefficients for $\mu_{c}$ were not significantly different from 1 . In contrast, regression coefficients for $\mu_{\text {pol }}$ and $\mu_{\text {lip }}$ were low $(0.10$ to 0.44 ) and significantly $(p \leqslant 0.05)$ less than 1 (Table 8 ). For Dunaliella tertiolecta, the regression coefficient for $\mu_{\text {pro }}$ was significantly greater $(p \leqslant 0.05)$ for the 24 h than $12 \mathrm{~h}$ incubations and the regression coefficient for $24 \mathrm{~h}$ was not significantly different from 1. For Thalassiosira
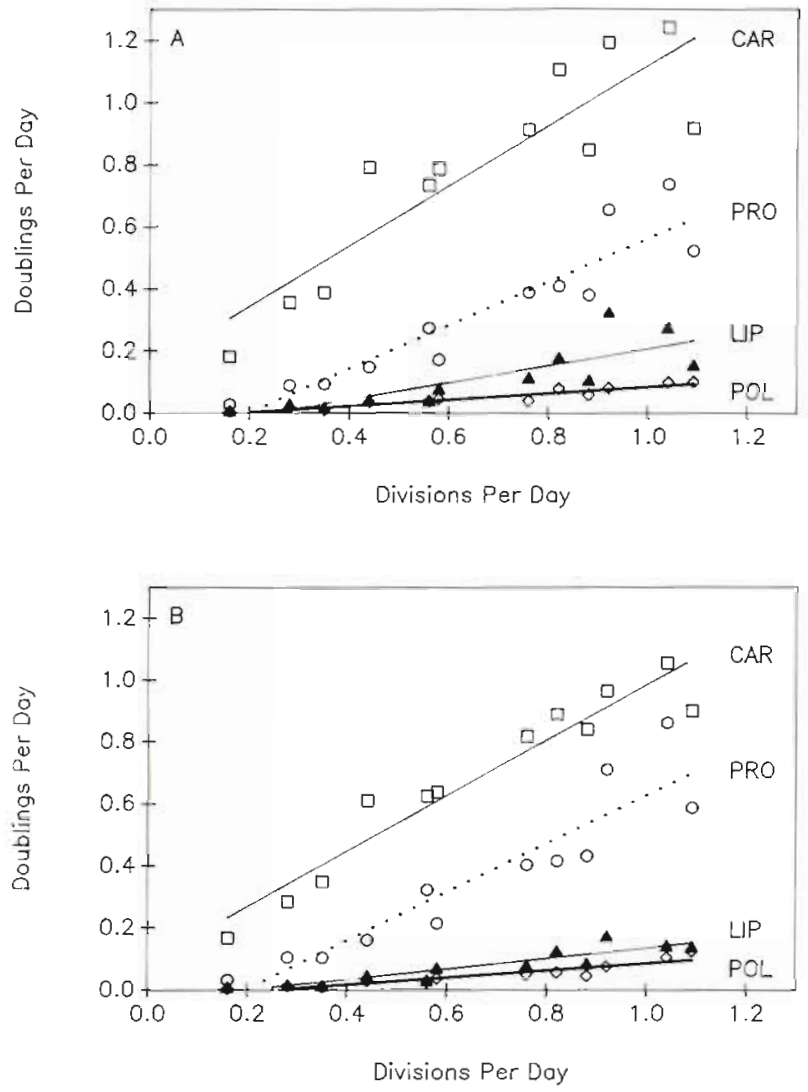

Fig. 7 Thalassiosira rotula. Relationship between rates of cell division (divisions $\mathrm{d}^{-1}$ ) and carbon (CAR) ( $\square$ ), protein (PRO) (0), polysaccharide (POL) (O), and lipid (LIP) ( $₫$ ) specific growth (doublings $\mathrm{d}^{-1}$ ) determined during (A) $12 \mathrm{~h}$ incubations in the light and (B) $24 \mathrm{~h}$ incubations (12 h light: $12 \mathrm{~h}$ dark)

rotula, the regression coefficients for $\mu_{\text {pro }}$ were the same $(0.70$ to 0.78$)$ for the 12 and $24 \mathrm{~h}$ incubations and were significantly $(p \leqslant 0.05)$ less than 1.

\section{DISCUSSION}

Only light which is absorbed produces photobiological effect (i.e. Grotthus-Draper law), hence, to experimentally demonstrate that cell metabolism is altered by spectral quality, the number of quanta which can be absorbed by the alga must be equal (Yentsch 1974, Morris 1981). Although the influence of light quality on algal metabolism has been periodically examined for over $20 y r$, comparing the results of different studies must be done with caution. The spectral distribution for the same 'color' may not be identical and the PUR (or PAR) may not be equal for the different spectral distributions. Therefore, differences in metabolism or growth among different algal species within the same study and for the same species in different studies may 
Table 8. Dunaliella tertiolecta and Thalassiosira rotula. Summary of regression statistics for linear relations between rates of cell division and carbon, protein, polysaccharide and lipid specific growth at 4 irradiances and 3 spectral qualities of light. Rates of

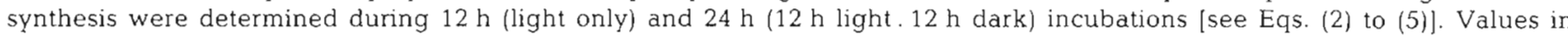
parentheses are standard errors $(n=12)$

\begin{tabular}{|c|c|c|c|c|}
\hline & \multicolumn{2}{|c|}{ Dunaliella tertiolecta } & \multicolumn{2}{|c|}{ Thalassiosira rotula } \\
\hline & $12 \mathrm{~h}$ & $24 \mathrm{~h}$ & $12 \mathrm{~h}$ & $24 \mathrm{~h}$ \\
\hline \multicolumn{5}{|l|}{ Carbon } \\
\hline & + & + & + & + \\
\hline Slope & $1.21(0.20)$ & $1.05(0.06)$ & $0.90(0.15)$ & $0.97(0.08)$ \\
\hline Intercept & $-0.04(0.10)$ & $-0.02(0.03)$ & $0.15(0.16)$ & $0.09(0.08)$ \\
\hline$r^{2}$ & 0.79 & 0.97 & 0.80 & 0.92 \\
\hline \multicolumn{5}{|l|}{ Protein } \\
\hline & $*$ & $*+$ & & \\
\hline Slope & $0.62(0.11)$ & $0.97(0.12)$ & $0.70(0.09)$ & $0.78(0.10)$ \\
\hline Intercept & $-0.02(0.05)$ & $-0.09(0.06)$ & $-0.09(0.14)$ & $-0.15(0.10)$ \\
\hline$r^{2}$ & 0.78 & 0.86 & 0.81 & 0.86 \\
\hline \multicolumn{5}{|c|}{ Polysaccharide } \\
\hline & $*$ & * & & \\
\hline Slope & $0.44(0.09)$ & $0.23(0.06)$ & $0.10(0.01)$ & $0.11(0.01)$ \\
\hline Intercept & $-0.04(0.04)$ & $-0.02(0.03)$ & $-0.02(0.01)$ & $-0.03(0.02)$ \\
\hline$r^{2}$ & 0.70 & 0.57 & 0.85 & 0.90 \\
\hline \multicolumn{5}{|l|}{ Lipid } \\
\hline Slope & $0.39(0.08)$ & $0.41(0.14)$ & $0.27(0.06)$ & $0.17(0.02)$ \\
\hline Intercept & $-0.02(0.04)$ & $-0.02(0.07)$ & $-0.07(0.06)$ & $-0.03(0.02)$ \\
\hline$I^{2}$ & 0.70 & 0.47 & 0.67 & 0.84 \\
\hline \multicolumn{5}{|c|}{ *: Significant difference between $12 \mathrm{~h}$ and $24 \mathrm{~h}$ values $(p \leq 0.05)$} \\
\hline
\end{tabular}

not reflect chromatic adaptations. During this study, the number of 'potentially absorbable quanta' (i.e. PUR; Morel 1978, Gostan et al. 1986) of white, blue and red light were equal. Thus, the effects of irradiances and spectral quality on metabolism and growth can be distinguished and the responses of different taxa can be compared.

This study presents the first rigorous statistical analysis of the results of factorial design experiments in which the effects of irradiance, spectral composition and incubation time on the metabolism and growth of marine phytoplankton were evaluated. By using ANOVA and a posteriori testing of differences among means, it was possible to simultaneously distinguish the effects of, and interactions among, the 3 independent variables on the metabolism, chemical composition and growth of phytoplankton (Sokal \& Rohlf 1969). Both the irradiance and spectral quality significantly influenced the chemical composition and the patterns and rates of synthesis of carbon and complex polymers but not the rate of cell division. Cell volume was not significantly influenced by the photic regime, therefore differences in chemical composition resulted from changes in the pattern of synthesis rather than simply reflecting changes in cell size.
The rates of dark respiration by Dunaliella tertiolecta and Thalassiosira rotula were significantly greater in blue and red than white light of equal PUR. Although blue light enhancement of dark respiration has been extensively studied (see Senger \& Briggs 1981 and Kowallik 1982 for reviews), the precise mechanism of enhancement remains unclear. In some algae, the higher concentration and activity of respiratory enzymes (Kowallik 1982, Ruyters 1984) in blue light may increase the rate of catabolism of carbohydrates. Consequently, cell protein may be relatively greater under blue light conditions (Kowallik 1970, 1982, Ruyters et al. 1984). Both red as well as blue light stimulation of respiration was recently reported for $D$. tertiolecta (Ruyters et al. 1984, Ruyters 1988). The results of this study are consistent with blue/red light enhancement of respiration. The similar rates of cell division of $D$. tertiolecta and $T$. rotula in all spectral regimes may, in part, reflect the similar responses of both photosynthesis and respiration to blue, red and white light.

The percent ${ }^{14} \mathrm{C}$ in the PRO, POL, LIP and LMW compounds were relatively constant after a 3 to $6 \mathrm{~h}$ incubation in the light (Table 5). Thus, by the end of the light period (i.e. $12 \mathrm{~h}$ ), the polymer pools were in isotopic equilibrium. In other marine phytoplankton, 
isotopic equilibrium among metabolite was typically reached within 2 to $12 \mathrm{~h}$ (Cuhel et al. 1984, Smith \& Geider 1985, Hitchcock 1986). Since the polymer pools were in isotopic equilibrium, changes in the ${ }^{14} \mathrm{C}$ activity in proteins or other polymer pools during the dark interval reflects net polymer synthesis or catabolism rather than turnover.

Reallocation of carbon among polymer pools and net synthesis of proteins in the dark has been reported for phytoplankton in laboratory cultures (Morris et al. 1974, Morris 1981, Harding et al. 1985) and from natural marine and freshwater populations (Morris 1981, Cuhel et al. 1984, Rivkin 1985, Cuhel \& Lean 1987a, b, Laws et al. 1987). In this study, there was a net synthesis of proteins at night. The carbon for protein synthesis was reallocated primarily from POL and LMW compounds in Dunaliella tertiolecta (Fig. 4) and from LIP and LMW compounds in Thalassiosira rotula (Fig. 5). These patterns were irradiance and spectral quality dependent. For example, in $D$. tertiolecta, night-time synthesis of proteins occurred at $\geqslant 40$ $\mu$ Einst. $\mathrm{m}^{-2} \mathrm{~s}^{-1}$ of white or red light, and at $\geqslant 12 \mu$ Einst. $\mathrm{m}^{-2} \mathrm{~s}^{-1}$ of blue light. Reallocation of carbon into protein in the dark was usually greater when daytime irradiances were high than low (Table 4). In contrast, in $T$. rotula, the increase in the protein pool at night was less dependent on daytime irradiance than was $D$. tertiolecta (Fig. 5). The patterns of carbon reallocation are species-specific in both laboratory cultures (Harding et al. 1985) and natural populations (Rivkin 1985). Thus, geographic and seasonal differences in the nocturnal patterns of carbon metabolism by natural assemblages may reflect either the responses of the phytoplankton to different environmental factors or differences in the composition of the phytoplankton community. Furthermore, since there are distinct diurnal and nocturnal patterns of carbon metabolism (Cuhel et al. 1984, Rivkin 1985, Cuhel \& Lean $1987 \mathrm{a}$, b), studies on the synthesis and turnover of organic polymers must include at least one diel cycle.

The rates of carbon, protein, polysaccharide and lipid specific growth were linearly related to the cell division rate (Figs. 6 and 7 ; Table 8 ). For each polymer, the slope of the relation between polymer-specific growth and cell division was independent of light quality. This linearity requires the influence of the photic regime on the rates and patterns of anabolism and catabolism of the individual polymers to be similar. The slopes of these relations differed between species and among most of the polymer fractions. Except for carbon and protein (Table 8), the slopes were significantly less than 1. These data suggest that, except for carbon (and perhaps protein), the rates of cell division or growth cannot be reliably estimated from turnover of the specific polymer pools. Moreover, the estimation of growth rates from the incorporation of ${ }^{14} \mathrm{C}$ into proteins (DiTullio \& Laws 1986 , Laws et al. 1987) was highly dependent on the incubation time and species composition (Table 8). In contrast, $\mu_{c}$ (calculated from $24 \mathrm{~h}$ and $12 \mathrm{~h}$ incubations) and $\mu_{\mathrm{n}}$ were not significantly different (Table 8)

Rates of primary production are often estimated during on-deck incubations with incident light attenuated to in situ irradiances with neutral density filters. Therefore, the downwelling intensity but not the spectral quality is simulated. In oceanic regions, light is increasingly attenuated in the red region of the visible spectrum with increasing depth. This study, as well as others, has shown significant effects of the spectral quality in general, and blue light specifically, on rates of carbon uptake and patterns of polymer synthesis (Wallen \& Geen 1971c, Wood 1985, Glover et al. 1986, 1987, Pick \& Cuhel 1986 and references cited therein). Thus, depth-dependent patterns of metabolism and growth are influenced by both irradiance and spectral quality. A consequence of the enhancement of carbon uptake and protein synthesis, and the increase in the efficiency of growth in blue relative to white or red light (Glover et al. 1986, 1987), is that rates of primary production and the turnover of organic polymers measured during simulated in situ incubations may underestimate in situ processes. Most of the phytoplankton biomass in the ocean's surface layer are typically found near the base of the euphotic zone, where blue light predominates (Venrick et al. 1973, Cullen \& Eppley 1981, Gould 1987). Furthermore, since there are significant differences in the spectral responses among taxa (Wood 1985, Glover et al. 1986, 1987), the magnitude of the influence of spectral quality on estimates of primary production would reflect the species composition of the phytoplankton population. The results of this and other studies clearly demonstrate the importance of considering spectral quality in models of photoadaptation and primary production.

Acknowledgements. I thank L. Gaudet and S. Sawyer for help with the experiments, $K . M$. Smith for graphics and $M$. R. Anderson for advice on statistical analyses. M. R. Anderson, D. Gustafson, $T$. Jones and 2 anonymous reviewers made helpful comments on the manuscript. This research was supported by research grants from the National Science Foundation No OCE 8300739 and 8516214 . University of Maryland, Center for Environmental and Estuarine Studies Contribution n.o. 2018.

\section{LITERATURE CITED}

Bligh, E. E., Dyer, W. J. (1959). A rapid method of total lipid extraction and purification. Can. J, Biochem. Physiol. 37: 911-917

Cosper, E. (1982). Influence of light intensity on diel variations in rates of growth, respiration and organic release of a marine diatom: comparisons of diurnally constant and fluctuating light. J. Plankton Res. 4: 705-724 
Cuhel, R. L., Lean, D. R. S. (1987a). Protein synthesis by lake plankton measured using in situ carbon dioxide and sulfate assimilation. Can. J. Fish. Aquat. Sci. 44: 2102-2117

Cuhel, R. L., Lean, D. R. S. (1987b). Influence of light intensity, light quality, temperature and daylength on uptake and assimilation of carbon dioxide and sulfate by lake plankton. Can. J. Fish. Aquat. Sci. 44: 2118-2132

Cuhel, R. L., Ortner, P. B., Lean, D. R. S. (1984). Night synthesis of protein in algae. Limnol. Oceanogr 29: 731-744

Cullen, J. J., Eppley, R. W. (1981). Chlorophyll maximum layers of the southern California Bight and possible mechanism of their formation and maintenance. Oceanologica Acta 4: 23-32

Cullen, J. J., Lewis, M. R. (1988). The kinetics of algal photoadaptation in the context of vertical mixing. J. Plankton Res. 10: 1039-1063

DiTullio, G. R., Laws, E. A. (1983). Estimates of phytoplankton $\mathrm{N}$ uptake based on ${ }^{14} \mathrm{CO}_{2}$ incorporation into proteins. Limnol. Oceanogr. 28: 177-185

DiTullio, G. R., Laws, E. A. (1986). Diel periodicity of nitrogen and carbon assimilation in five species of marine phytoplankton: accuracy of methodology for predicting $\mathrm{N}$ assimilation and N/C composition ratios. Mar. Ecol. Prog. Ser. 32: 123-132

Dubois, M., Giles, K. A., Hamilton, J. K., Rebers, P. A., Smith, F. (1956). Colormetric method for determination of sugars and related substances. Analyt. Chem. 28: 350-356

Einot, I., Gabriel, K. R. (1975). A study of the powers of several methods of multiple comparisons. J. Am. Statist. Ass. 70: 351-364

Falkowski, P. G. (1980). Light-shade adaptation in marine phytoplankton. In: Falkowski, P. G. (ed.) Primary productivity in the sea. Plenum Press, New York, p. 99-119

Falkowski, P. G. (1983). Light-shade adaptation and vertical mixing of marine phytoplankton. A comparative field study. J. mar Res. 41: 215-237

Falkowski, P. G., Dubinsky, Z., Wyman, K. (1985). Growth irradiance relationships in phytoplankton. Limnol. Oceanogr. 30: 311-321

Faust, M. A., Sager, J. C., Meeson, B. W. (1982). Response of Prorocentrum mariae-lebouriae (Dinophyceae) to light of different spectral qualities and irradiances: growth and pigmentation. J. Phycol. 18: 349-356

Glover, H. E., Keller, M. D., Guillard, R. R. L. (1986). Light quality and oceanic ultraphytoplankters. Nature, Lond. 319: $142-143$

Glover, H. E., Keller, M. D., Spinard, R. W. (1987). The effects of light quality and intensity on photosynthesis and growth of marine eukaryotic and prokaryotic phytoplankton clones. J. exp. mar. Biol. Ecol. 105: 137-159

Gostan, J., Lechuga-Deveze, C., Lazzara, L. (1986). Does blue light affect the growth of Chaetoceros protuberans (Bacillariophyceae)? J. Phycol. 22: 63-71

Gould, R. W. (1987). The deep chlorophyll maximum in the world ocean: a review. The Biologist 66: $4-13$

Guillard, R. R., Ryther, J. H. (1962). Studies of marine plankton diatoms 1. Cyclotella nana Hustedt and Detonula confervacea (Cleve) Gran. Can. J. Microbiol. 8: 229-239

Harding, L. W., Meeson, B. W., Fisher, T. R. (1985). Patterns of photosynthetic carbon metabolism in light-limited phytoplankton. Mar. Biol. 89: 121-133

Harris, G. P. (1978). Photosynthesis, productivity and growth. The physiological ecology of phytoplankton. Arch. Hydrobiol. Beih. Ergeb. Limnol. 10: 1-171

Hitchcock, G. L. (1983). Photosynthate partitioning in cultured marine phytoplankton. 1. Dinoflagellates. J. exp. mar. Biol. Ecol. 69: 21-36
Hitchcock, G. L. (1986). Methodological aspects of time course measurements of ${ }^{14} \mathrm{C}$ fixation in marine phytoplankton. J. exp. mar. Biol. Ecol. 96: 233-243

Jerlov, N. G. (1968). Optical oceanography. Elsevier Press, Amsterdam

Jukes, T H., Holmquist, R., Moise, H. (1975). Amino acid composition of proteins. Selection against the genetic code. Science 189: 50-51

Kirk, J. T. O. (1983). Light and photosynthesis in aquatic ecosystems. Cambridge Univ. Press, Cambridge

Kowallik, W. (1970). Light effects on carbohydrate and protein metabolism in algae. In: Haldall, P. (ed.) Photobiology of microorganisms. Wiley-Interscience, New York, p. $165-185$

Kowallik, W. (1982). Blue light effects on respiration. Ann. Rev. Plant Physiol. 33: 51-72

Laws, E. A., Wong, D. C. L. (1978). Studies of carbon and nitrogen metabolism by three phytoplankton species in nitrate limited continuous cultures. J. Phycol. 14: 723-731

Laws, E. A., DiTullio, G. R., Redalje, D. G. (1987). High phytoplankton growth and production rates in the North Pacific tropical gyre. Limnol. Oceanogr. 32: 905-918

Lewis, M. R., Horne, E. P. W., Cullen, J. J., Oakley, N. S., Platt $T$ (1984). Turbulent motions may control phytoplankton photosynthesis in the upper ocean. Nature, Lond. 311: $49-50$

Lewis, M. R., Ulloa, O., Platt, T. (1988). Photosynthetic action, absorption and quantum yield spectra for a natural population of Oscillatoria in the North Atlantic. Limnol. Oceanogr. 33: 92-98

Lewis, M. R. Warnock, R. E., Irwin, B., Platt, T. (1985a). Measuring photosynthetic action spectra of natural phytoplankton populations. J. Phycol. 21: 310-315

Lewis, M. R., Warnock, R. E., Platt, T. (1985b). Absorption and photosynthetic action spectra for natural phytoplankton populations: implications for production in the open ocean. Limnol. Oceanogr. 30: 794-806

Li, W. K. W., Glover, H. E., Morris, I. (1980). Physiology of carbon assimilation by Oscillatoria thiebantii in the Caribbean Sea. Limnol. Oceanogr. 25: 447-456

Lowry, O. H., Rosenbrough, A. L., Farr, A. L., Randell, R. J. (1951). Protein measurement with the Folin phenol reagent. J. Biol. Chem. 193: 265-275

Miller, R. G. (1981). Simultaneous statistical inferences. Springer-Verlag, New York

Morgan, D. C., Smith, H. (1981). Non-photosynthetic responses to light quality. In: Lange, O. L., Nobel, P. S., Osmond, C. B., Ziegler, H. (eds.) Physiological plant ecology I. Responses to the physical environment. Springer-Verlag, New York, p. 109-134

Morel, A. (1978). Available, useable and stored radiant energy in relation to marine photosynthesis. Deep Sea Res. 25: $673-688$

Morel, A., Lazzara, L., Gostan, J. (1987). Growth rate and quantum yield time response for a diatom to changing irradiances (energy and color). Limnol. Oceanogr. 32 1066-1084

Morris, I. (1981). Photosynthesis products, physiological state, and phytoplankton growth. Can. Bull. Fish. Aquat. Sci. 210: 83-102

Morris, I., Glover, H. E., Yentsch, C. S. (1974). Products of photosynthesis by marine phytoplankton: the effect of environmental factors on the relative rates of protein synthesis. Mar. Biol. 27: 1-9

Olive, J. H., Morrison, J. H. (1967). Variations in distribution of ${ }^{14} \mathrm{C}$ in cell extracts of phytoplankton living under natural conditions. Limnol. Oceanogr. 12: 383-391 
Pande, S. V., Parvan Khan, R., Ventkitasubramanian, T A (1963). Microdetermination of lipids and total serum fatty acids. Analyt. Biochem. 6: 415-423

Pick, F. R., Cuhel, R. L. (1986). Light quality effects on carbon and sulfur uptake of a metalimnetic population of the colonial chrysophyte Chrysosphaerella longispina. In: Kristiansen, J., Andersen, R. A. (eds.) Chrysophytes: aspects and problems. Cambridge Univ. Press, Boston, p. 197-205

Prézelin, B. B. (1981). Light reactions of photosynthesis. Can. Bull. Fish. Aquat. Sci. 210: 1-45

Reeck, G. R., Fisher, L. (1973). A statistical analysis of the amino acid compositions of proteins. Int. J. Peptide Protein Res. 5: 109-117

Richardson, K., Beardall, J., Raven, J. A. (1983). Adaptations of unicellular algae to irradiance: an analysis of strategies. New Phytol. 93: 157-191

Rivkin, R. B. (1985). Carbon-14 labelling patterns of individual marine phytoplankton from natural populations: a species approach. Mar. Biol. 89: 135-142

Ruyters, G. (1984). Effects of blue light on enzymes. In: Senger, $H$. (ed.) Blue light effects in biological systems Springer-Verlag, New York, p. 283-301

Ruyters, G. (1988). Light-stimulated respiration in the green alga Dunaliella tertiolecta: involvement of the ultraviolet/ blue-light photoreceptor(s) and phytochrome? Planta 174 $422-425$

Ruyters, G., Hirosawa, T., Miyachi, S. (1984). Blue light effects on carbon metabolism in Dunaliella. In: Senger, H. (ed.) Blue light effects in biological systems. Springer-Verlag, New York, p. 317-322

Senger, H., Briggs, W. R. (1981). The blue light photoreceptor(s): primary reactions and subsequent metabolic changes. Photochem. Photobiol. Rev. 13: 1-38

This article was presented by Dr T. Platt, Dartmouth, Canada
Sharp, J. H. (1977). Excretion of organic matter by marine phytoplankton: do healthy cells do it? Limnol. Oceanogr. 22: $381-399$

Smith, R. E. H., Geider, R. J. (1985). Kinetics of intracellular carbon allocation in a marine diatom. J. exp. mar. Biol Ecol. 93: 191-210

Smucker, R. A., Dawson, R. (1986). Products of photosynthesis by marine phytoplankton: chitin in TCA 'protein' precipitates. J. exp. mar. Biol. Ecol 104: 143-152

Sokal, R. R., Rohlf, F. J. (1969). Biometry. Freeman Press, San Francisco

Truper, H. G., Yentsch, C. S. (1967). Use of glass fiber filters for the rapid preparation of in vivo absorption spectra of photosynthetic bacteria. J. Bacteriol. 94: 1255-1256

Venrick, E. L., McGowan, J. A., Mantyla, A. W (1973). Deep maxima of photosynthetic chlorophyll in the Pacific Ocean. Fish. Bull. U.S. 71:41-52

Wallen, D. G., Geen, G. H. (1971a). Light quality in relation to growth, photosynthetic rates and carbon metabolism in two species of marine plankton algae. Mar. Biol. 10: 34-43

Wallen, D. G., Geen, G. H. (1971b). Light quality and concentration of protein, RNA, DNA and photosynthetic pigments in two species of marine phytoplankton. Mar. Biol. 10: $44-51$

Wallen, D. G., Geen, G. H. (1971C). The nature of the photosynthate in natural phytoplankton populations in relation to light quality. Mar. Biol. 10: 157-168

Wood, A. M. (1985). Adaptation of the photosynthetic apparatus of marine ultraplankton to natural light fields. Nature, Lond. 316: 253-255

Yentsch, C. S. (1974). Some aspects of the environmental physiology of marine phytoplankton: a new look. Oceanogr. mar. Biol A. Rev. 12: 41-75

Manuscript first received: January 16, 1989

Revised version accepted: May 2, 1989 